Article

\title{
Comparative Study on the Behavior of Virgin and Recycled Polyolefins-Cellulose Composites in Natural Environmental Conditions
}

\author{
Iuliana Raut, Mariana Calin, Zina Vuluga $₫$, Elvira Alexandrescu, Melania Liliana Arsene, \\ Violeta Purcar, Cristian-Andi Nicolae, Ana Maria Gurban ${ }^{\circledR}$, Mihaela Doni and Luiza Jecu * \\ National Institute for Research \& Development in Chemistry and Petrochemistry-ICECHIM, Spl. \\ Independentei 202, 060021 Bucharest, Romania; iulia_rt@yahoo.com (I.R.); marriconstantin@yahoo.com (M.C.); \\ zvuluga@yahoo.com (Z.V.); elviraalexandrescu@yahoo.com (E.A.); melania_arsene@yahoo.com (M.L.A.); \\ violetapurcar@hotmail.com (V.P.); ca_nicolae@yahoo.com (C.-A.N.); amgurban@yahoo.com (A.M.G.); \\ mihaela.doni@icechim.ro (M.D.) \\ * Correspondence: jecu.luiza@icechim.ro; Tel.: +40-0213163063
}

Received: 13 May 2019; Accepted: 27 May 2019; Published: 15 June 2019

\begin{abstract}
Polypropylene-cellulose composites have great potential in many important commercial applications, and it is important to understand and properly evaluate their biodegradative behavior to achieve improved composite formulations in accordance with their future applications. In the present study, an outdoor soil burial test was performed in order to evaluate the susceptibility to degradation of polyolefins-cellulose composites. The structural and morphological changes were analyzed by Fourier transform infra-red spectroscopy with attenuated total reflectance (FTIR-ATR) and scanning electron microscopy (SEM). The weight loss of composite samples after burying in soil was recorded. The presence of new bands, as an indicator of degradation, was confirmed by FTIR-ATR spectra. The thermal stability of the composites after soil burial analyzed by TGA was slightly improved, with relatively higher temperatures being required to decompose the samples after exposure to environmental factors. SEM micrographs presented some modifications of the polymer surface, such as holes, cracks, exfoliations, and fractures. Increasing the cellulose percentage of the composite samples led to increased weight loss. From the obtained results, it can be concluded that composites based on polyolefins and renewable resources undergo a slow process of biodegradation after contact with environmental microorganisms and, with appropriate composition, could be applied to various environmental fields.
\end{abstract}

Keywords: composites; microbial degradation; polyolefins; virgin or recycled polypropylene

\section{Introduction}

Polypropylene (PP) is the most widely used thermoplastic polymer, presenting mechanical properties desirable for various applications. Likewise, PP is a suitable polymer matrix for obtaining composites with great potential in many important commercial applications. Several reports have described the production of composites containing natural lignocellulosic fibers from agro-industry [1-9]. Cellulose, the most abundant natural polymer, is considered a good filler with which to produce composite materials. Cellulose-polyolefins composites have found applications in numerous engineering fields, such as automotive applications, structural components, packaging, and construction (panels, window frames, decking, etc.) [10-12].

Cellulose-plastic composites are based on two polymers: a natural polymer hydrophilic cellulose and a hydrophobic synthetic polymer matrix of polypropylene. Since the polymers have different properties, it is necessary to improve the adhesion degree between both components by adding 
a compatibilizer, usually based on maleic anhydride. These materials combine the advantages of cellulose and polyolefin polymers. The use of cellulose as a filler is advantageous because of its high accessibility as a renewable resource, low cost, shape flexibility, low susceptibility to fracturing during processing, and small "carbon footprint". Therefore, it is important to understand and properly evaluate the biodegradative behavior for better composite formulations in accordance with future applications. Plastic waste management includes prevention, reuse, and recycling, and disposal is the last resort [13-15].

Interest in this domain is demonstrated by the great number of publications dedicated to natural fiber-reinforced composites. A comprehensive review was done by Faruk et al. (2013) [16], who highlighted the factors to be considered in these composites, the importance of sources and types of natural fibers, the manufacturing techniques to be used, and the properties of final product. They considered that green composite materials could be the material revolution of this century. Chauhan et al. (2012) [17] analyzed the properties of a broad range of fibers, such as hemp, flax, jute, kenaf, sisal, and ramie, as reinforcement materials for composite materials. In many cases, these reinforcements improved the mechanical behavior due to the compatibility between fibers and the polymer matrix. Ku et al. (2011) [18] provided a comprehensive overview of the influence of fibers in natural fiber-reinforced polymer composites in terms of the tensile properties of the materials. Mohammed et al. (2015) [4] presented a well-documented review evaluating the characteristics and properties of natural fiber-reinforced polymer composites, and analyzed various surface treatments (enzymatic, chemical) applied to natural fibers. The future development and extension of composite material applications were discussed by Sahari and Sapuan (2011) [19]. Another perspective on polymer-fiber composites was reported in a comprehensive review on the dynamic mechanical properties of these composites with industrial applications as construction and building materials. They considered that natural fiber-reinforced polymer composites would ensure "greener, sustainable, and smart construction development" [20].

The aim of the study was to assess composite modifications induced by soil microorganisms using several techniques, such as Fourier transform infra-red spectroscopy with attenuated total reflectance (FTIR-ATR), thermogravimetric analysis (TGA), and scanning electron microscopy (SEM). The samples' weight loss over time in the soil environment was also recorded. The composites were prepared with virgin (vPP) and recycled polypropylene (rPP) at different cellulose loadings, using maleic anhydride-grafted polypropylene as the compatibilizer. The recyclability of polypropylene at the end of its useful life is economically beneficial and contributes to environmental protection by reducing plastic disposal.

\section{Materials and Methods}

\subsection{Materials}

Virgin high flow PP polymer BJ380MO (vPP) produced by Borealis AG, Wienna, Austria (white color) was kindly donated by FPK LIGHTWEIGHT TECHNOLOGIES S.COOP. rPP (granules of black color) were from auto pieces of local plastic recycling plant. Maleic anhydride grafted polypropylene (MAPP), Polybond 3200 from Crompton Corporation, Middlebury, USA, was used as compatibilizing agent. Cellulose fibers were purchased from LA.SO.LE. Est SRL, Percoto, Italy.

\subsection{Composites Preparation}

The composites were obtained in dynamical conditions, in a Brabender Plastograph, by directly incorporating 20,30 , or $40 \%$ of the filler into vPP or rPP melt, at $160 \pm 5{ }^{\circ} \mathrm{C}, 100 \mathrm{rpm}$, and $7 \mathrm{~min}$. Maleic anhydride as compatibilizing agent $(2.5 \% \mathrm{w} / \mathrm{w}$ of the weight of PP) was included in materials mixture. The composites were pressed at a temperature of $190{ }^{\circ} \mathrm{C}$ for 2 min to obtain plates of $100 \mathrm{~mm} \times$ $100 \mathrm{~mm} \times 0.5 \mathrm{~mm}$. The nomenclature, composition, and some characteristics of samples are presented in Table 1. 
The techniques for the evaluation of biodegradation were applied to polymeric composites before and after microorganism contact. The composites are distinguished by " $\mathrm{i}$ " as initial (before soil burial) and "s" (after soil burial).

Table 1. Characteristics of materials investigated.

\begin{tabular}{lll}
\hline Abbreviation & Material Composition & Form and Characteristics \\
\hline rPP & recycled polypropylene from auto pieces & plate; black color; $0.5 \mathrm{~cm}$ thickness \\
rPP 20cell & $80 \%$ rPP+ 20\% cellulose fiber & plate; black color; $0.5 \mathrm{~cm}$ thickness \\
rPP 30cell & $70 \%$ rPP + 30\% cellulose fiber & plate; black color; $0.5 \mathrm{~cm}$ thickness \\
rPP 40cell & $60 \%$ rPP + 40\% cellulose fiber & plate; black color; $0.5 \mathrm{~cm}$ thickness \\
vPP & virgin polypropylene & plate; white color; relative transparent; $0.5 \mathrm{~cm}$ thickness \\
vPP 20cell & $80 \%$ vPP + 20\% cellulose fiber & plate; chestnut color; $0.5 \mathrm{~cm}$ thickness \\
vPP 30cell & $70 \%$ vPP $+30 \%$ cellulose fiber & plate; chestnut color; $0.5 \mathrm{~cm}$ thickness \\
vPP 40cell & $60 \%$ vPP $+40 \%$ cellulose fiber & plate; chestnut color; $0.5 \mathrm{~cm}$ thickness \\
\hline
\end{tabular}

\subsection{Soil Burial Test}

The plastic samples were cut into pieces of $1.0 \mathrm{~cm} \times 2.5 \mathrm{~cm} \times 0.5 \mathrm{~cm}$ and buried in garden soil at the depth of $15 \mathrm{~cm}$. The samples were exposed to natural weathering, such as rain, sunlight, snow etc. for 24 months.

To evaluate the biodegradation percentage by weight loss $(\mathrm{B} \%)$, the pieces were taken off carefully from the soil and washed gently with distilled water to remove the soil particles, kept overnight at room temperature, and then kept in dessicator till constant weight. The samples were weighed and the biodegradation percentage was calculated using the following formula [21]:

$$
\mathrm{B} \%=\left[\left(\mathrm{W}_{\mathrm{i}}-\mathrm{W}_{\mathrm{s}}\right) / \mathrm{W}_{\mathrm{i}}\right] \times 100 \%
$$

where $\mathrm{W}_{\mathrm{i}}=$ initial weight of sample and $\mathrm{W}_{\mathrm{s}}=$ weight after burial soil.

\subsection{Characterization}

Morphological analysis of polymers was carried out by scanning electron microscopy (SEM) on FEI-QUANTA 200. The samples were placed on metallic support, aluminum standard stub, using a double-sided adhesive carbon tape. The SEM images were taken at an accelerating voltage of $30 \mathrm{kV}$. Micrographs of the samples were analysed at different magnifications to identify changes on the surface during the degradation process. For each polymeric sample, 4-6 micrographs were performed and only relevant images were presented.

Fourier transform infrared analysis (FTIR-ATR) spectra were acquired using a FT-IR, tensor 37 spectrometer (Bruker, Billerica, MA, USA) with ATR golden gate. All samples were recorded from 400 to $4000 \mathrm{~cm}^{-1}$.

Thermal stability was proved by TGA with a TGA Q5000IR (TA instruments, New Castle, DE, USA). Samples (50-10 mg) were heated from 20 to $700{ }^{\circ} \mathrm{C}$ at a $10{ }^{\circ} \mathrm{C} / \mathrm{min}$ scanning rate, under nitrogen atmosphere (flow rate about $200 \mathrm{~mL} \cdot \mathrm{min}$ ). The onset temperature (Ton) was determined as the temperature corresponding to the crossover of tangents drawn on both sides of the decomposition trace, and the residue was evaluated as the residual weight at $700{ }^{\circ} \mathrm{C}$. TGA analysis was applied to composites before and after burial soil. Additionally, cellulose, rPP, and vPP were individually analyzed for the thermal stability.

\section{Results and Discussions}

Environmental degradation involves both biotic and abiotic factors. Abiotic factors refer to non-living factors (sunlight, water, soil types, pollutants and nutrients, and pH values), while biotic factors mean the involvement of living organisms. Soil burial is a traditional and standard method for the investigation of biodegradation process, occuring in similar conditions to those suffered by wastes disposed on soil [22-25]. 


\subsection{Weight Loss Determination}

During the burial soil test period of 24 months, the polyolefins- based composites exhibited the normal weather changes, such as rain, snow, sun irradiation, and wind. No water or nutrients were added to soil, since the natural microorganisms from the soil were able to produce a certain level of biodegradation. As shown in Figure 1, some modifications of the color and aspect could be observed, especially for vPP-cellulose composites.

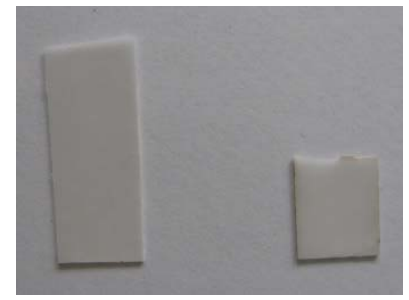

(a)

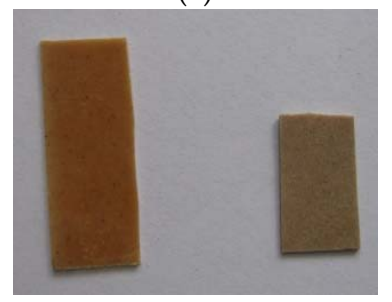

(c)

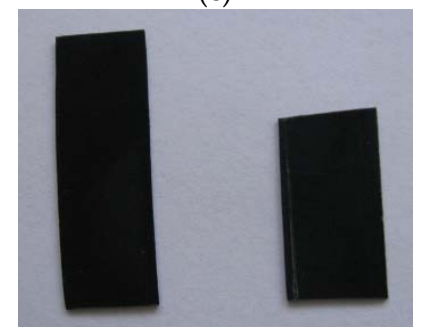

(e)

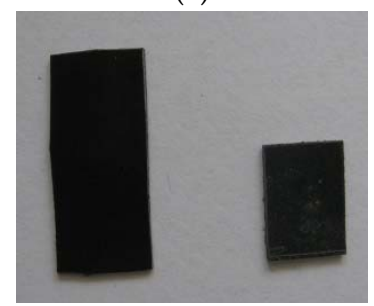

(g)

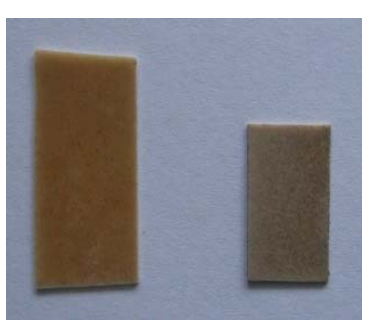

(b)

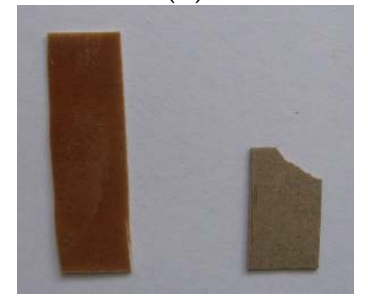

(d)

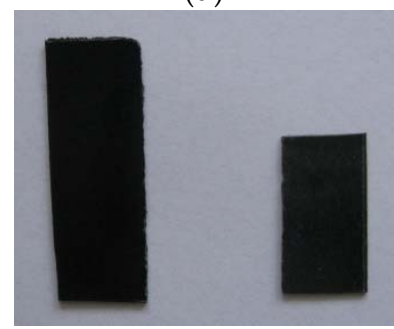

(f)

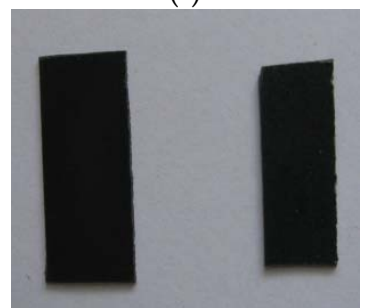

(h)

Figure 1. Images of composites before and after burial soil (left-samples before soil burial; right-samples after soil burial). (a) virgin (vPP), (b) vPP 20cell, (c) vPP 30cell, (d) vPP 40cell, (e) recycled polypropylene (rPP), (f) rPP 20cell, (g) rPP 30cell, and (h) rPP 40cell.

The percentage of composites weight loss could be considered an indicator of biodegradation level (Figure 2).

The decrease in weight observed for of the samples after soil burial is due to degradation of cellulosic component through hydrolytic depolymerization to monomeric glucose units produced by soil microorganisms, fungi, and bacteria. Generally, polymers biodegradation occurs through three main steps: (i) attachment of the microorganism to polymer surface; (ii) microbial growth using the polymer as a carbon source; and (iii) final polymer degradation up to certain compounds, depending on biodegradation mechanism pathways, whether anaerobic or aerobic [26,27]. The biodegradation of polymer composites in natural environment is governed by several factors, including the type of 
microorganisms, soil characteristics (humidity, temperature, and $\mathrm{pH}$ ), and polymer features (molecular weight, type of functional groups and substituents present in its structure, and crystallinity) [28]. Sometimes, plasticizers or additives can play a role in biodegradation.



Figure 2. Weight loss of composites after 24 months of soil burial.

As expected, in our experiments the changes of weight for vPP and rPP components were very minor after 24 months of soil burial, $0.60 \%$ for vPP, and $0.55 \%$ for $\mathrm{rPP}$, respectively. Generally, the values of mass loss were higher for all composites based on vPP, compared to those based on rPP. This finding is due to the multi stages heat processing of rPP component that induced a higher resistance to microbial degradation of rPP composites. It is known that rPP, being more compact, is characterized by higher density and lower porosity $[29,30]$. The presence of cellulose filler favored the biodegradation, with the increasing of cellulose content to $40 \%$ leading to a weight loss of $13.75 \%$ for vPP 40 cell and $14.50 \%$ for rPP 40cell, respectively.

A number of studies have been published on the biodegradation extent of various composites based on polyolefins-natural components. Thus, it was reported that the degradation of pure low-density polyethylene (LDPE) and LPDE-20\% (corn or potato) starch blends into the soil for 8 months leads to only $0.5 \%(\mathrm{w} / \mathrm{w})$ of weight loss [31]. Polypropylene composites prepared by extrusion of PP resin with $5,10,15$, and $20 \mathrm{wt} \%$ of potato starch exhibited a biodegradation increase of up to $10.6 \%$ after 120 days of being buried in soil [32]. Composites with polypropylene-cellulose fibers extracted from rice straw buried in soil for 50 days have been degraded from about 3 to $23 \mathrm{wt} \%$, depending on filler content [33]. Pure and thermally pretreated polypropylene films exposed to in vitro biodegradation for 12 months, in a minimal medium with mixed soil culture, exhibited a weight loss of $10.7 \%$ and $0.4 \%$, respectively [34].

\subsection{Surface Morphology}

SEM provides information about surface morphology of polymeric sheets. The technique was employed in many studies to visualize the extent of microbial degradation by polymer composite samples buried in soil [2,21,35-37]. The surface of samples became damaged and irregular with cracks, holes, exfoliation, and fractures (Figures 3 and 4). This is a general phenomenon observed in the case of thermoplastics filled with natural fibers. 


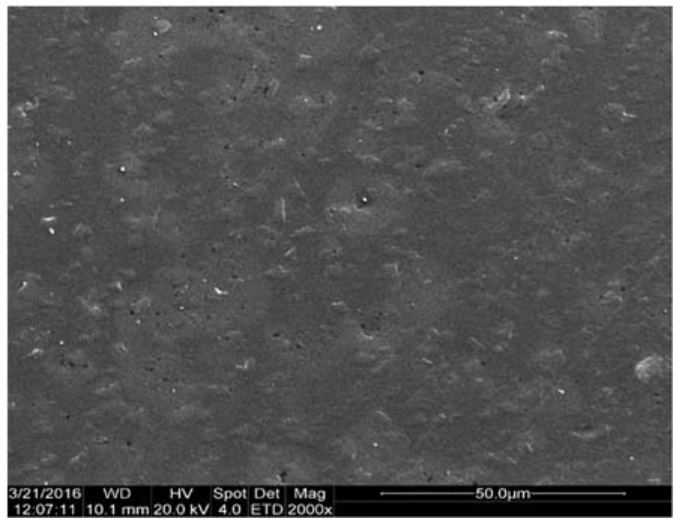

(a)

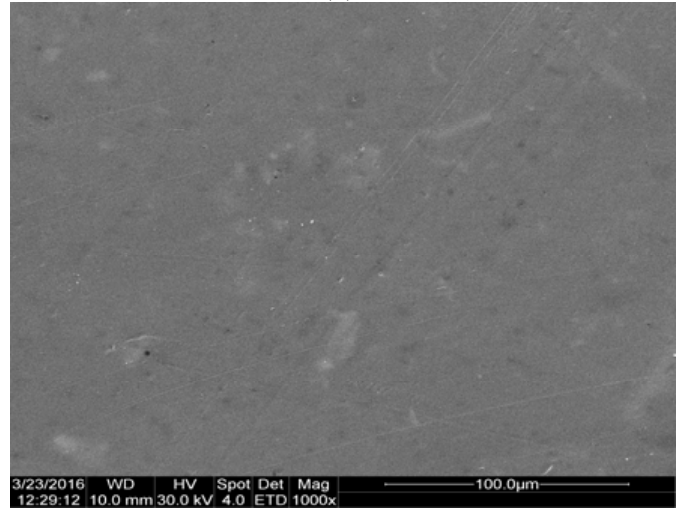

(c)

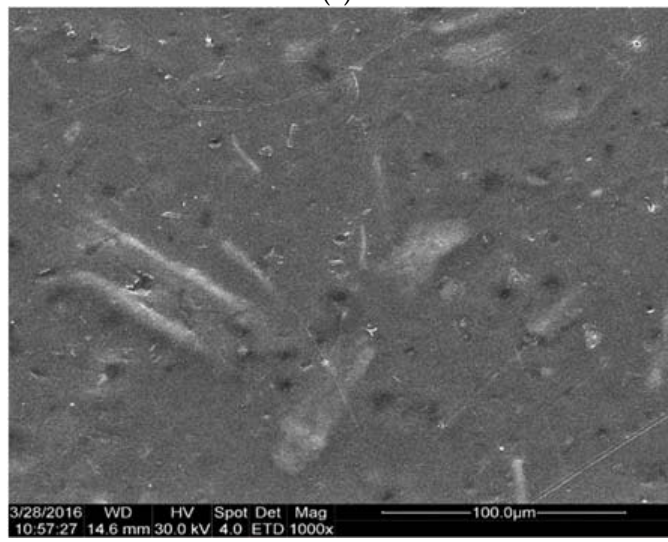

(e)

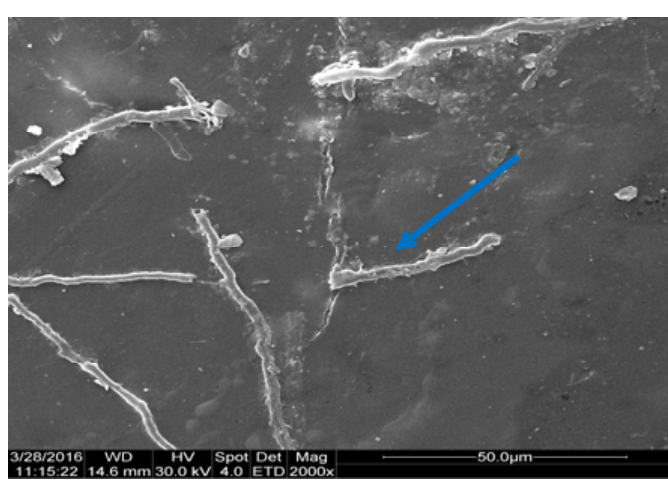

(g)

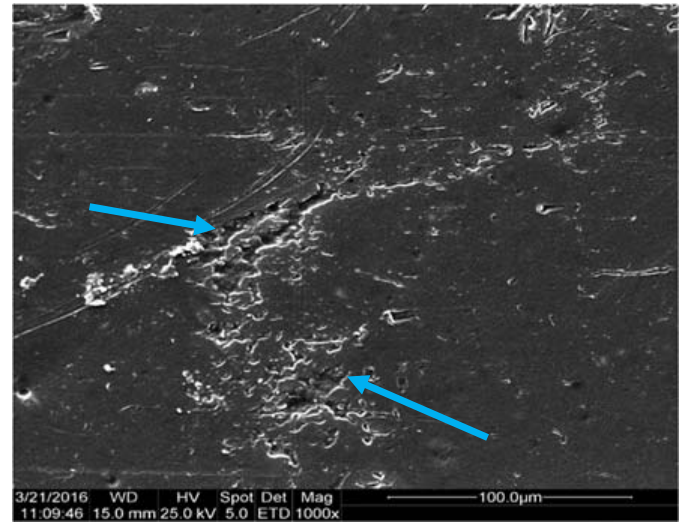

(b)

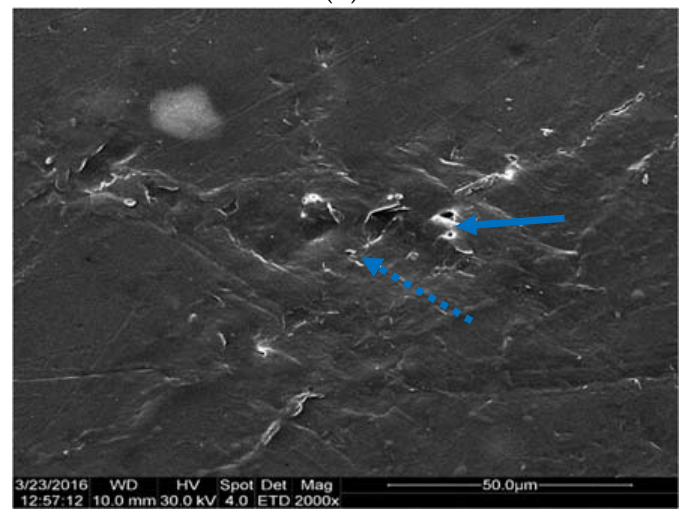

(d)

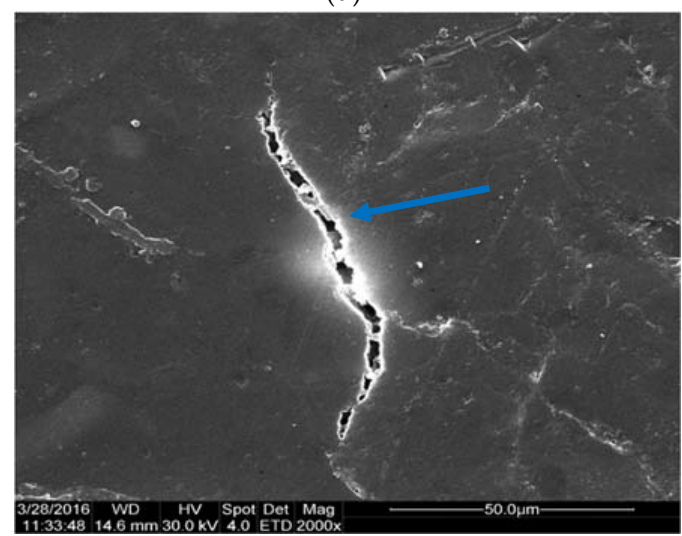

(f)

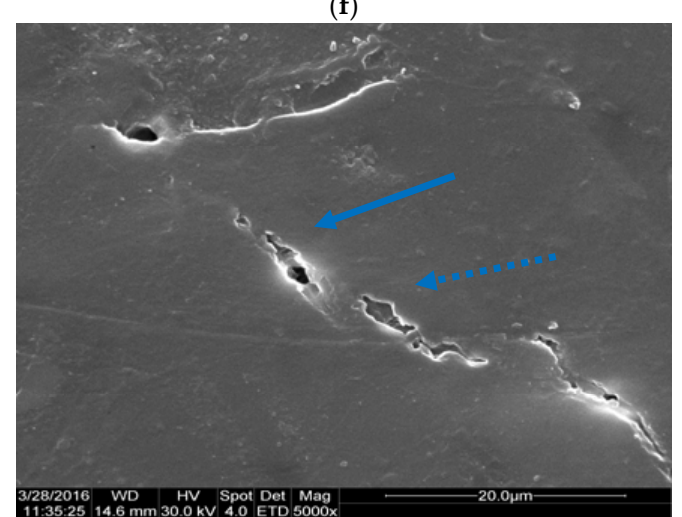

(h)

Figure 3. Cont. 


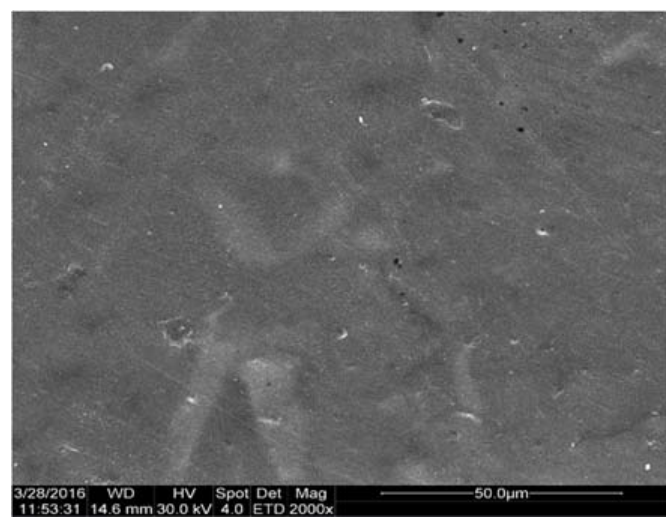

(i)

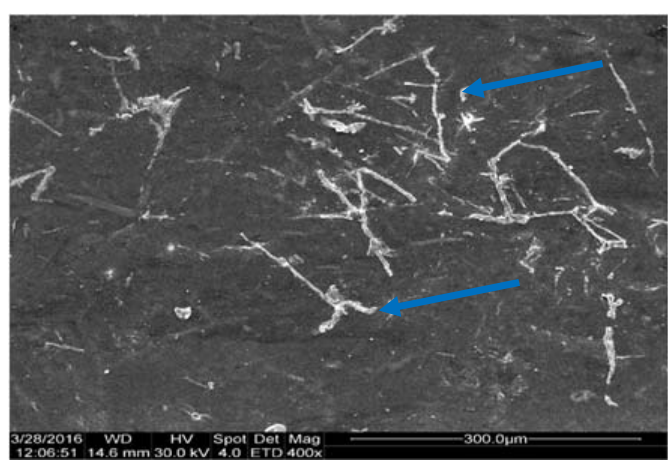

$(\mathbf{k})$

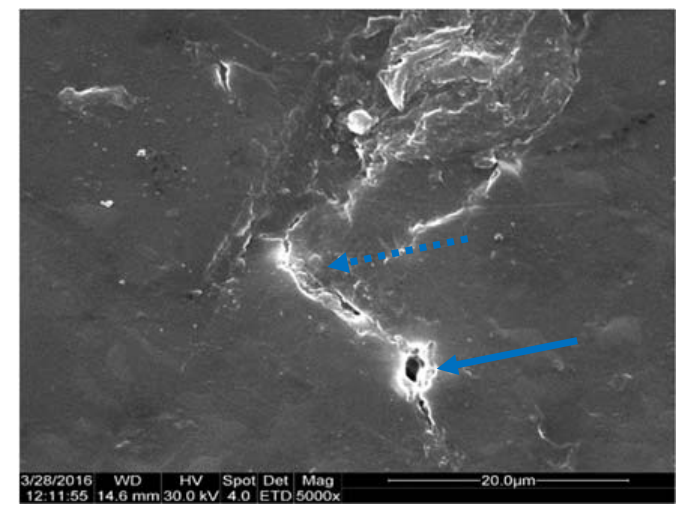

(j)

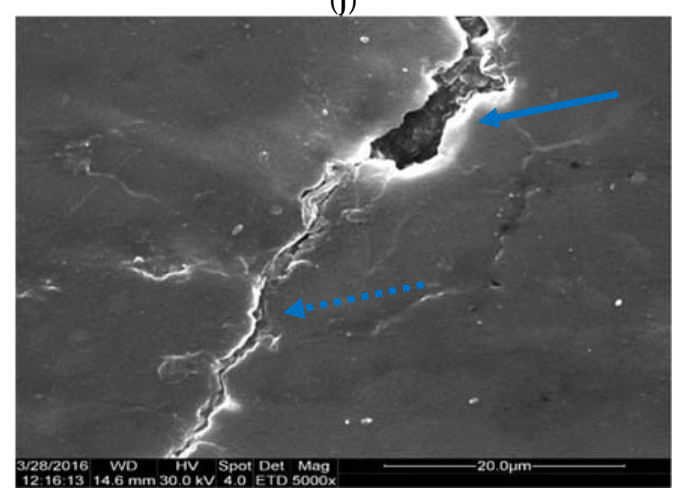

(1)

Figure 3. SEM images of the vPP-cellulose composites' surface biodegradation. (a) vPP before soil burial (2000×), (b) vPP after soil burial (arrow—damages extended on surface; 1000×), (c) vPP 20cell before soil burial 1000×), (d) vPP 20cell after soil burial (arrow—void; dotted arrow-surface exfoliation; 2000×), (e) vPP 30cell before soil burial (1000×), (f) vPP 30cell after soil burial (arrow-deep and extended fracture; 2000×), (g) vPP 30cell after soil burial network of flattened hyphae on material surface; 2000×), (h) vPP 30cell after soil burial (arrow-void; dotted arrow -surface fracture and exfoliation; 2000×), (i) vPP 40cell before soil burial (2000×), (j) vPP 40cell after soil burial (arrow-void; dotted arrow-fracture; 5000x), (k) vPP 40cell after soil burial (arrow-flattened hyphae network, 400×), and (1) vPP 40cell after soil burial (arrow-deep crater; dotted arrow-surface fracture; 5000×).



(a)

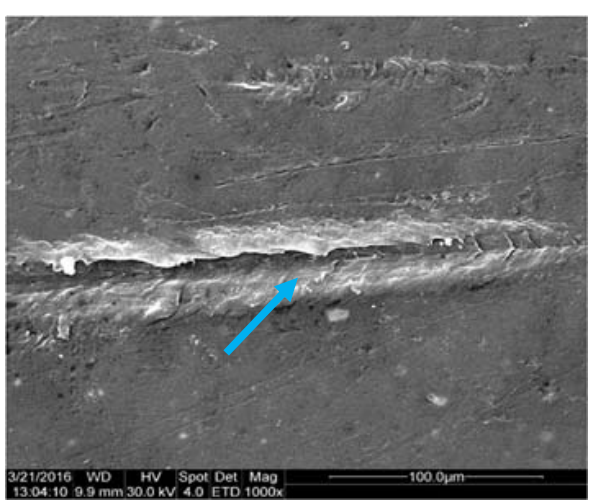

(b)

Figure 4. Cont. 




(c)

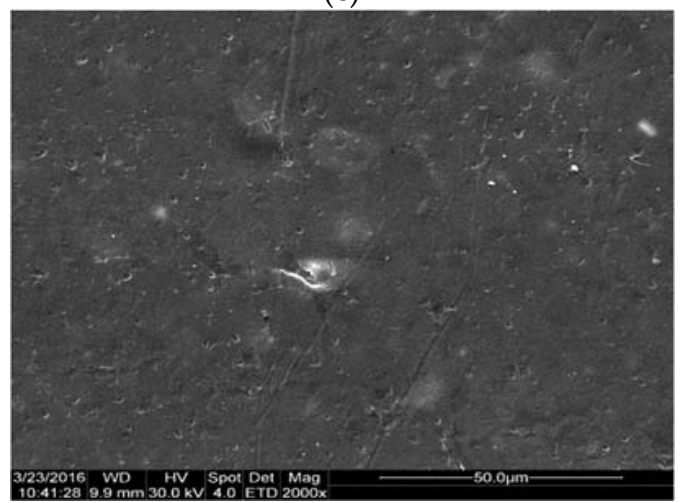

(e)

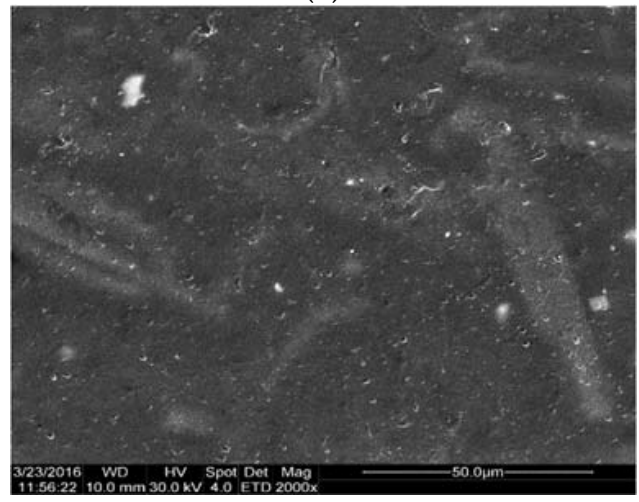

(g)

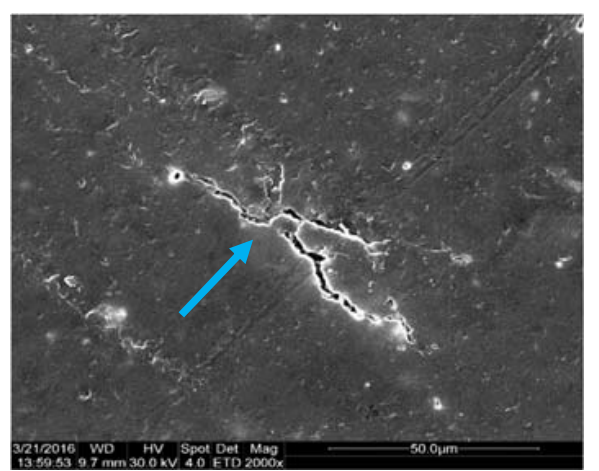

(d)

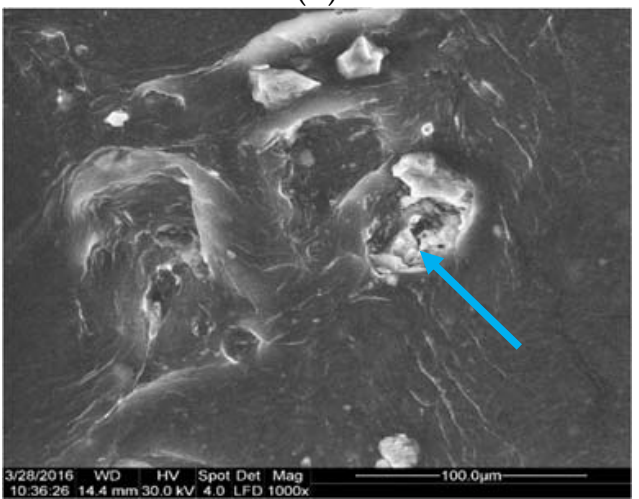

(f)

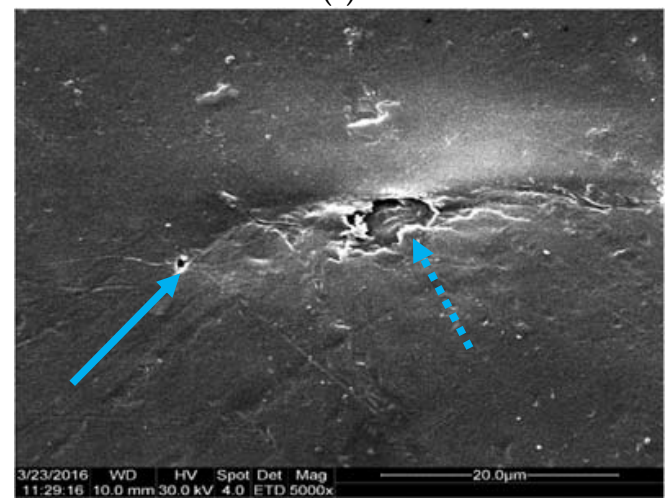

(h)



(i)

Figure 4. SEM images of the rPP-cellulose composites surface biodegradation. (a) rPP before soil burial $(2000 \times)$, (b) rPP after soil burial (arrow-surface exfoliation; 1000×), (c) rPP 20cell before soil burial $(1000 \times)$, (d) rPP 20cell after soil burial (arrow-surface fracture; 2000×), (e) rPP 30cell before soil burial $(2000 \times)$, (f) rPP 30cell after soil (burial arrow—damaged surface;1000×), (g) rPP 40cell before soil burial (2000×), (h) rPP 40cell after soil (burial arrow—void; dotted arrow—surface exfoliation; 2000×), and (i) rPP 40cell after burial soil (arrow-traces of fungal hyphae attached to composite surface). 
Generally, the initial vPP-cellulose composites have a smooth surface compared with rPP samples, and among all samples, those with $40 \%$ cellulose are more flattened. After soil burial, the samples exhibited different modifications in correlation with their composition. For all initial samples, SEM images reveal the presence of some voids, fractures, or scratches (Figure 3a,c,e,g; Figure 4a,c,e,g), which could indicate a poor interaction between the non-polar matrix of polyolefin and polar filler-cellulose. As the result of soil microorganisms-induced degradation, a series of morphological changes can be observed: damages extended on composite surface at vPP (Figure 3b); voids and surface exfoliation at vPP 20cell (Figure 3d); extended fracture with deep holes (Figure 3f) and fracture and exfoliation for vPP 30cell (Figure 3h); at vPP 40cell, voids and fracture (Figure 3j); traces of flattened fungal hyphae (Figure 3k); and deep crater connected to a long fracture for vPP 40c3ll (Figure 31).

A lower degradation of the samples containing rPP (Figure 4) compared to vPP samples was observed. A surface exfoliation was evidenced at rPP (Figure 4b), while rPP 20cell presented surface fracture (Figure $4 \mathrm{~d}$ ). The surface of rPP 30cell was damaged without producing holes or cracks (Figure 4f). Discrete voids and surface exfoliation were seen in images of rPP 40cell composites (Figure 4h). Fungal hyphae filaments attached to surface were visible (Figure 4i).

\subsection{FTIR-ATR Analysis}

FTIR-ATR analysis was applied to assess the structural modifications induced by microorganisms', revealing the rate of biodegradation based on the reduction or disappearance of some existing bonds after exposure to environment microorganisms. FTIR-ATR spectrum of cellulose presents the following characteristic bands: band at $3340 \mathrm{~cm}^{-1}$ assigned to hydroxyl groups stretching, bands at $2897 \mathrm{~cm}^{-1}$ and $1368 \mathrm{~cm}^{-1}$ assigned to stretching and deformation vibrations of $\mathrm{C}-\mathrm{H}$ group in glucose, band at $1027 \mathrm{~cm}^{-1}$ assigned to $-\mathrm{C}-\mathrm{O}-$ group of secondary alcohols and ethers functions from cellulose chain backbone, and band at $898 \mathrm{~cm}^{-1}$ characteristic of $\beta$-glycosidic linkage between glucose units [38].

In the case of recycled and virgin initial polypropylene (PP), the following bands have been identified: $2953 \mathrm{~cm}^{-1}, 2916 \mathrm{~cm}^{-1}$, and $\sim 2840 \mathrm{~cm}^{-1}$ assigned to $\mathrm{C}-\mathrm{H}$ stretching; $1456 \mathrm{~cm}^{-1}$ assigned to $\mathrm{C}-\mathrm{H}_{2}$ bending; $1374 \mathrm{~cm}^{-1}$ assigned to $\mathrm{C}-\mathrm{H}_{3}$ bending; $1163 \mathrm{~cm}^{-1}$ assigned to $\mathrm{C}-\mathrm{H}$ bending, $\mathrm{CH}_{3}$ rocking, and $\mathrm{C}-\mathrm{C}$ stretching; in the range $800-1000 \mathrm{~cm}^{-1}$ assigned to $\mathrm{CH}_{3}$ rocking, $\mathrm{C}-\mathrm{C}$ stretching, and $\mathrm{C}-\mathrm{H}$ and $\mathrm{C}-\mathrm{H}_{3}$ bendings. The spectrum was in accordance with literature data [39].

Some changes can be observed in FTIR-ATR spectra of composite samples after burial soil (Figure 5): (i) relative intensification of band in the range of $1725-1740 \mathrm{~cm}^{-1}$ assigned to carbonyl group, as an indicator of microorganisms activity and others factors upon composite samples and (ii) presence of the new bands (visible only to certain samples) at $1640-1650 \mathrm{~cm}^{-1}$ assigned to protein materials from microorganisms. The band around $1640-1650 \mathrm{~cm}^{-1}$ is due to $\mathrm{N}-\mathrm{H}$ or $\mathrm{C}-\mathrm{N}$ groups from $\mathrm{N}$-acetyl-glucosamine units existing in soil fungi [40].

These observations are in line with the findings of others reports that mention an increase in carbonyl band after exposure to abiotic environment [34]. 


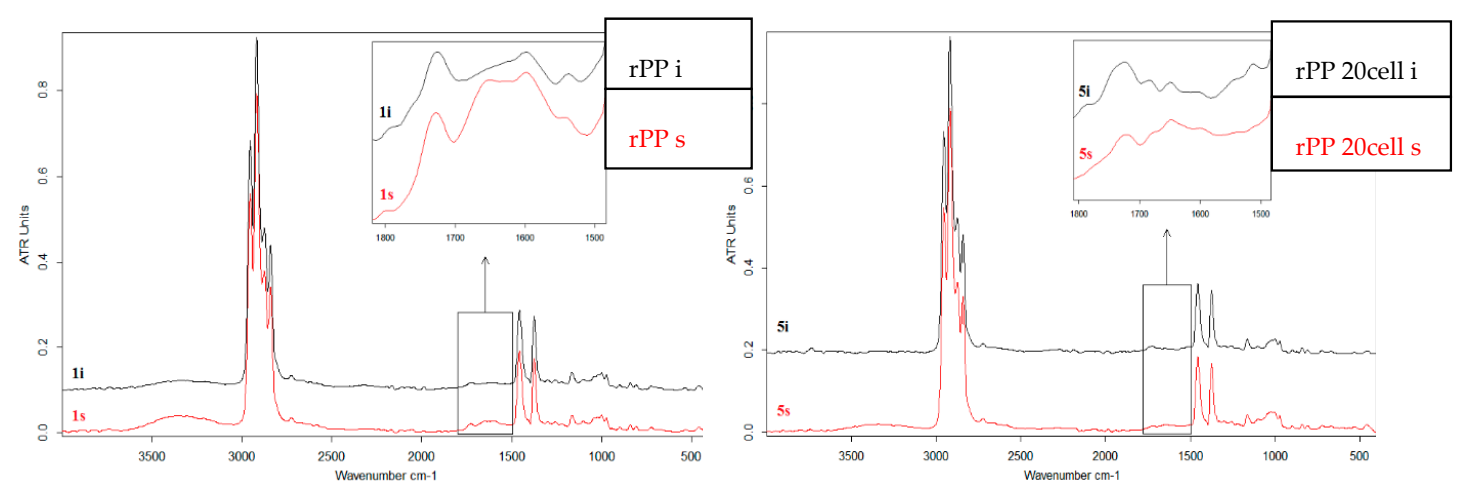

(a)

(b)

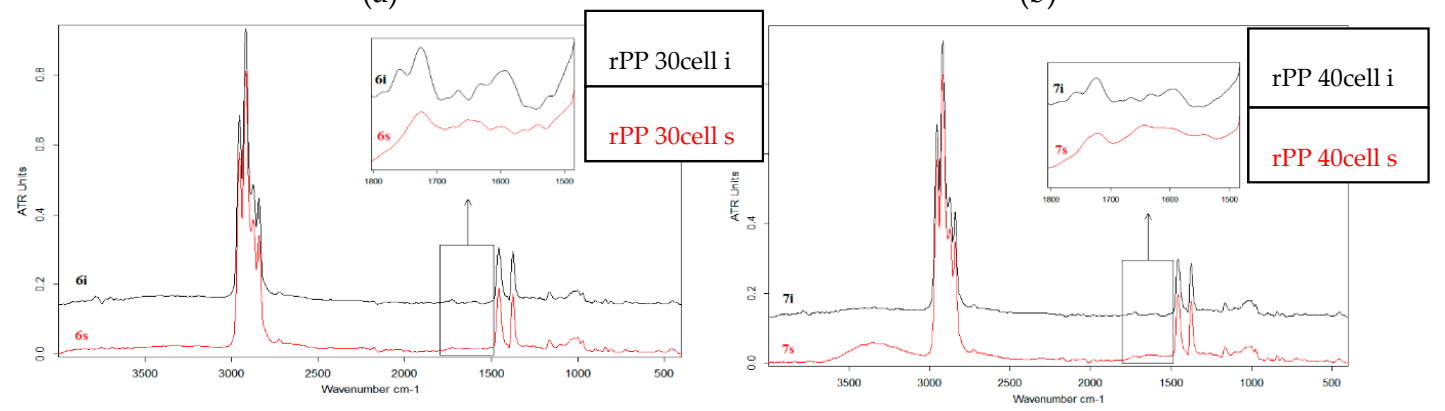

(c)

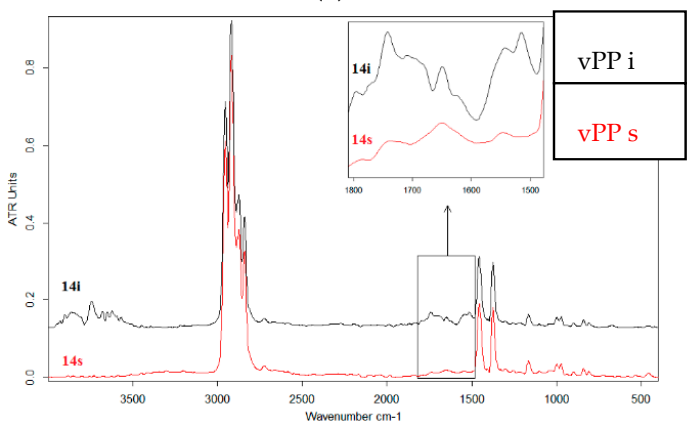

(e)

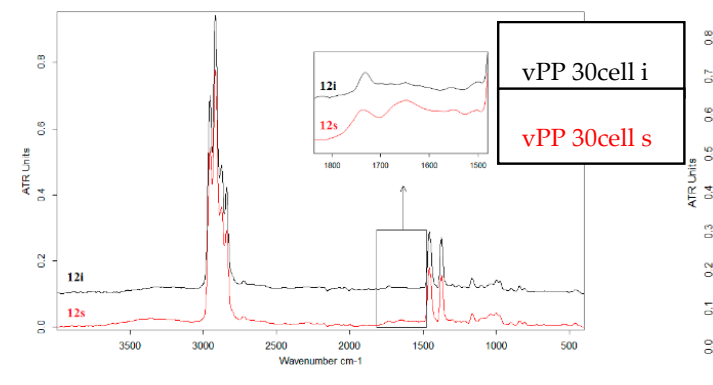

$(\mathrm{g})$ (d)

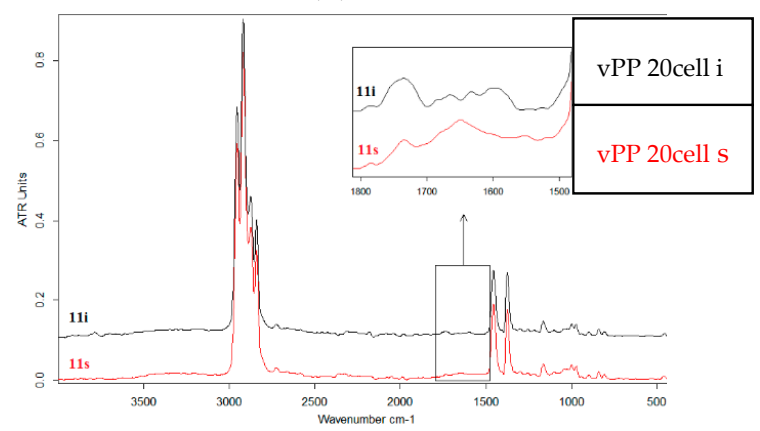

(f)

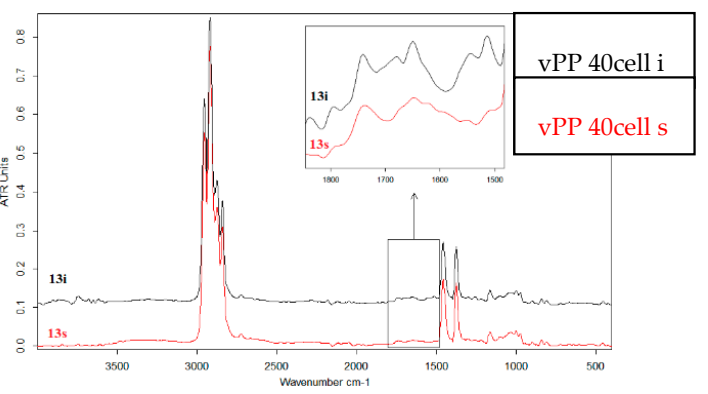

(h)

Figure 5. Fourier transform infra-red spectroscopy with attenuated total reflectance (FTIR-ATR) spectra of vPP and rPP-cellulose composites before and after soil burial ( $\mathrm{i}=$ initial sample; $\mathrm{s}=$ soil buried sample). (a) rPP before and after soil burial; (b) rPP 20cell before and after soil burial; (c) rPP 30cell before and after soil burial; (d) rPP 40cell before and after soil burial; (e) vPP before and after soil burial; (f) vPP 20cell before and after soil burial; (g) vPP 30cell before and after soil burial; (h) vPP 40cell before and after soil burial. 


\subsection{Thermogravimetric Analysis (TGA)}

TGA can determine the moisture content, thermal cleavage, thermal degradation temperature, and thermal stability of polyolefins based composites. Detailed data on thermal behavior is offered by analysis of TGA curve slope, as differential thermogravimetric analysis (Figure 6).

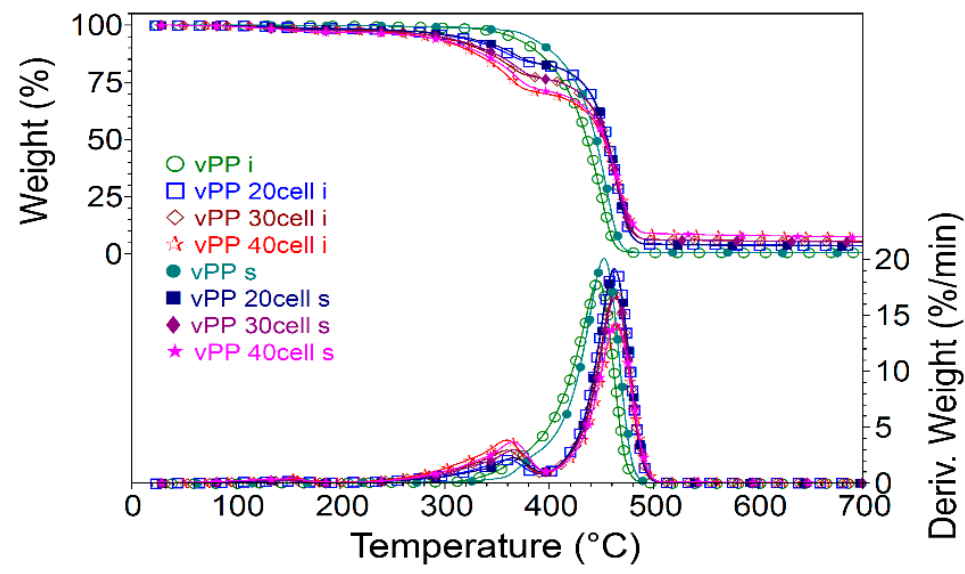

(a)

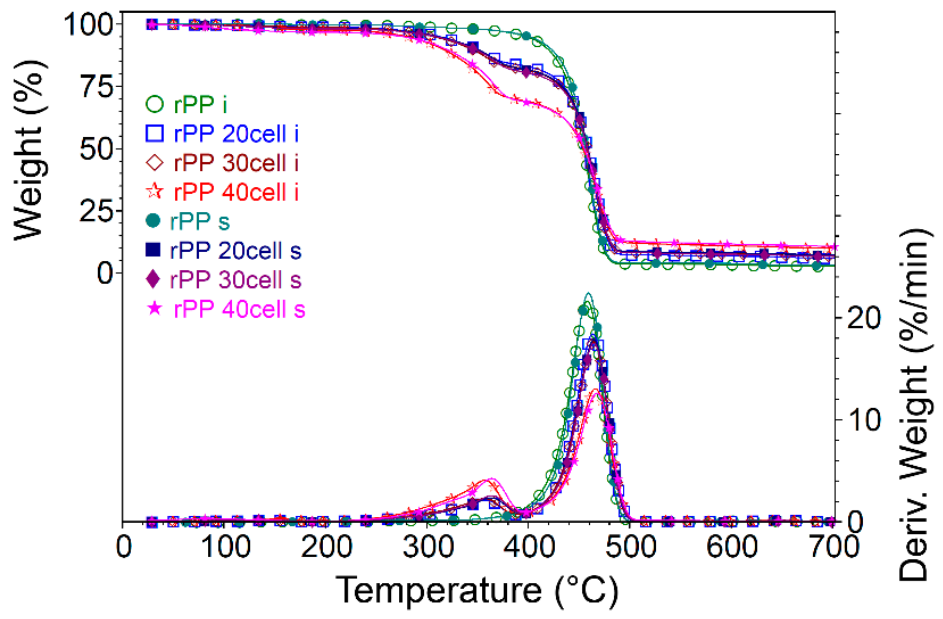

(b)

Figure 6. TGA curves of PP-cellulose composites. (a) vPP-cellulose composites and (b) rPP-cellulose composites.

The thermal stability of polymer depends on presence of monomers, aromatic rings and chemical bonds from main and side chains [41]. The evolution of weight loss in PP-cellulose composites showed typical patterns [34,42-44]. The PP-cellulose composites presented two main degradation steps. An initial weight loss was observed in the range of $30-180^{\circ} \mathrm{C}$, where water vaporization takes place. As expected, the weight loss increased with cellulose content, with the values being slightly higher for vPP cellulose samples, compared with those for rPP samples.

In the domain of $180-400{ }^{\circ} \mathrm{C}$, cellulose decomposed at maximum temperature of $361.3^{\circ} \mathrm{C}$, a loss of $70.46 \%$ from initial weight. All composite samples presented similar evolution profiles of the thermal degradation TGA. The thermal stability after burial soil was improved, with quite small temperature differences before and after soil burial. It can be said that higher temperatures are required to decompose the samples after exposure to environmental factors during the 24 months period. The thermal weight loss was around $16 \%$ for samples with $20 \%$ cellulose, with minor differences referring to polypropylene 
type. For composites with $30 \%$ cellulose, the weight loss was around $21 \%$ for vPP based composites, and around $17 \%$ for those with rPP. The weight loss values for samples containing $40 \%$ cellulose were almost similar: $28 \%$ for rPP composites and $27 \%$ for vPP composites, respectively.

Temperatures ranging from 400 to $555^{\circ} \mathrm{C}$ are specific to decomposition of polymeric components. The maximum decomposition in nitrogen atmosphere occurs at $458.4^{\circ} \mathrm{C}$ for $\mathrm{rPP}$, and $459.4^{\circ} \mathrm{C}$ for $\mathrm{rPP}$ $\mathrm{s}$, indicating an increase of only $1^{\circ} \mathrm{C}$. The temperature values for vPP before and after soil burial were slightly higher compared to rPP.

Normally, when lowering propylene concentration from $80 \%$ to $60 \%$, a decrease in weight loss of samples occurred from exposure to the decomposition temperature of polypropylene. Overall, thermal degradation of buried samples was shifted towards higher temperatures, noting that $\mathrm{rPP} / \mathrm{cellulose}$ composites presented a higher thermal stability than vPP. In connection with cellulose content, the values of weight loss decreased in the following order: PP 20cell (i, s)> PP 30cell (i, s)> PP 40cell (i, s). The specific degradation temperature of each individual component, rPP, vPP, or cellulose was lower than that obtained after mixing with filler in composites. This could be due to the protection exercised by the thermally more stable PP that surrounded the cellulosic fibers [43,45]. It is considered that cellulose fibers are able to immobilize the free radical released through polymer degradation, and to interact and finally inhibit the diffusion of volatile compounds resulting from degradation. The weight loss as residue in nitrogen atmosphere at $700{ }^{\circ} \mathrm{C}$ was $10.72 \%$ for $\mathrm{rPP} /$ cellulose composites and $7.51 \%$ for vPP/cellulose composites.

\section{Conclusions}

The main conclusions of the current study can be drawn as follows: (i) good resistance of proposed materials to natural environmental conditions, and thus a recommendation for possible outdoor applications; (ii) incorporation of plastic wastes, which is important for environmental protection and also for resources preservation; and (iii) high content of renewable sources, which is a positive aspect of resources preservation.

The modifications in morphology were shown by SEM micrographs as holes, cracks, exfoliation, and fractures of the composite surface. FTIR-ATR spectra of composites after soil burial presented a relative intensification of band in the range of $1725-1740 \mathrm{~cm}^{-1}$ assigned to carbonyl group, an indicator of changes in samples chemical structure. In some cases, new bands at 1640-1650 $\mathrm{cm}^{-1}$ assigned to protein materials from microorganisms were observed. All composite samples presented similar evolution profiles of the thermal degradation TGA, the thermal stability after burial soil being improved, with quite small temperature differences before and after burial soil. It can be said that higher temperatures are required to decompose the samples after exposure to environmental factors during the 24 months period.

As was expected, the increase of cellulose percentage in composite samples from $20 \%$ to $40 \%$ leads to the increase of weight loss after 24 months of burial soil. Maximum weight losses under the degradation conditions were obtained for the samples with $40 \%$ cellulose, $13.75 \%$ for rPP 40 cell, and $14.50 \%$ for vPP 40cell, respectively.

Of particular interest, pronounced notable differences of composite behavior were not found regarding the polymer type or virgin or recycled polypropylene, which is an encouraging result. Thus, the use of recycled polypropylene could contribute to the conservation of petrochemical resources and to reducing the negative impact on the environment of plastic waste accumulation.

Therefore, the results proved that polyolefins-cellulose composites exhibited a reduced biodegradation and may be used for various outdoor applications. Since there is a great interest in incorporating renewable natural resources into conventional plastics such as polypropylene, the research will focus on the design of such materials, taking into account some economic aspects like lower cost and easily manufacturability. Further studies will be pursued to determine their self life, to improve their durability upon consolidation and use. 
Author Contributions: Conceptualization, L.J. and M.L.A.; Investigation, I.R., M.C., E.A., C.-A.N., V.P., Z.V., and A.M.G.; Writing-L.J., I.R. and M.C.; Original Draft Preparation, L.J., M.L.A. and M.D.; Writing-Review and Editing, L.J., M.D. and M.L.A.; Visualization, L.J. and M.L.A.; Supervision, L.J., A.M.G. and M.L.A. All authors read and approved the final manuscript.

Funding: This research was funded by projects PN-II-PT-PCCA-2013-4-1709/085/2017 and PN.19.23.01.01.01/2019.

Acknowledgments: The authors thank to Ministry of Research and Innovation of Romania through Program 1: Development of the National Research and Development System; and Subprogram 1.2: Institutional performance-Projects of Excellence Financing in RDI, project number PFE no 31/2018.

Conflicts of Interest: The authors declare no conflict of interest. The funders had no role in the design of the study; in the collection, analyses, or interpretation of data; in the writing of the manuscript; or in the decision to publish the results.

\section{References}

1. Ashori, A. Wood-plastic composites as promising green-composites for automotive industries! Bioresour. Technol. 2008, 99, 4661-4667. [CrossRef] [PubMed]

2. Fakhrul, T.; Islam, M.A. Degradation behavior of natural fiber reinforced polymer matrix composites. Procedia Eng. 2013, 56, 795-800. [CrossRef]

3. Yashas Gowda, T.G.; Sanjay, M.R.; Subrahmanya Bhat, K.; Madhu, P.; Senthamaraikannan, P.; Yogesha, B. Polymer matrix-natural fiber composites: An overview. Cogent Eng. 2018, 5, 1446667. [CrossRef]

4. Mohammed, L.; Ansari, M.N.; Pua, G.; Jawaid, M.; Islam, M.S. A review on natural fiber reinforced polymer composite and its applications. Int. J. Polym. Sci. 2015, 243947. [CrossRef]

5. Patel, R.H.; Kapatel, P.M.; Machchhar, A.D.; Kapatel, Y.A. Studies on natural fiber reinforced polymer matrix composites. AIP Conf. Proc. 2016, 1728, 020233.

6. Tazi, M.; Erchiqui, F.; Kaddami, H. Influence of SOFTWOOD-fillers content on the biodegradability and morphological properties of WOOD-polyethylene composites. Polym. Compos. 2018, 39, 29-37. [CrossRef]

7. Tazi, M.; Erchiqui, F.; Godard, F.; Kaddami, H. Evaluation of mechanical properties and durability performance of HDPE-wood composites. AIP Conf. Proc. 2015, 1664, 150001.

8. Verbeek, C.J.R.; Pickering, K.L. Recent developments in polymer consolidated composites. J. Reinf. Plast. Compos. 2007, 26, 1607-1624. [CrossRef]

9. Yu, L.; Dean, K.; Li, L. Polymer blends and composites from renewable resources. Prog. Polym. Sci. 2006, 31, 576-602. [CrossRef]

10. Faruk, O.; Bledzki, A.K.; Fink, H.P.; Sain, M. Biocomposites reinforced with natural fibers: 2000-2010. Prog. Polym. Sci. 2012, 37, 1552-1596. [CrossRef]

11. Shalwan, A.; Yousif, B.F. In State of Art: Mechanical and tribological behaviour of polymeric composites based on natural fibres. Mater. Des. 2013, 48, 14-24. [CrossRef]

12. Ticoalu, A.; Aravinthan, T.; Cardona, F. A Review of Current Development in Natural Fiber Composites for Structural and Infrastructure Applications. In Proceedings of the Southern Region Engineering Conference (SREC 2010), Toowoomba, Australia, 10-12 November 2010.

13. Green Paper on a European Strategy on Plastic Waste in the Environment. Available online: http://www.reto rna.org/mm/file/CDR3751-2013_00_00_TRA_PAC_EN.pdf (accessed on 14 June 2019).

14. Fotopoulou, K.; Karapanagioti, H. Degradation of Various Plastics in the Environment; In: Hazardous Chemicals Associated with Plastics in the Marine Environment. In Hazardous Chemicals Associated with Plastics in the Marine Environment; Takada, H., Karapanagioti, H.K., Eds.; Springer International Publishing AG: Cham, Switzerland, 2017.

15. Narancic, T.; O'Connor, K.E. Microbial biotechnology addressing the plastic waste disaster. Microb. Biotechnol. 2017, 10, 1232-1235. [CrossRef] [PubMed]

16. Faruk, O.; Bledzki, A.K.; Fink, H.P.; Sain, M. Progress report on natural fiber reinforced composites. Macromol. Mater. Eng. 2014, 299, 9-26. [CrossRef]

17. Chauhan, A.; Chauhan, P.; Kaith, B. Natural fiber reinforced composite: A concise review article. J. Chem. Eng. Process Technol. 2012, 3. [CrossRef]

18. Ku, H.; Wang, H.; Pattarachaiyakoop, N.; Trada, M. A review on the tensile properties of natural fiber reinforced polymer composites. Compos. Part B Eng. 2011, 42, 856-873. [CrossRef] 
19. Sahari, J.; Sapuan, S.M. Natural Fibers and its composites for engineering applications: An overview. Rev. Adv. Mater. Sci. 2011, 30, 166-174.

20. Saba, N.; Jawaid, M.; Alothman, O.Y.; Paridah, M.T. A review on dynamic mechanical properties of natural fibre reinforced polymer composites. Constr. Build. Mater. 2016, 106, 149-159. [CrossRef]

21. Altaee, N.; El-Hiti, G.A.; Fahdil, A.; Sudesh, K.; Yousif, E. Biodegradation of different formulations of polyhydroxybutyrate films in soil. SpringerPlus 2016, 5, 762. [CrossRef]

22. Mumtaz, T.; Khan, M.R.; Hassan, M.A. Study of environmental biodegradation of LDPE films in soil using optical and scanning electron microscopy. Micron 2010, 41, 430-438. [CrossRef]

23. Sato, H.; Furuhashi, M.; Yang, D.; Ohtani, H.; Tsuge, S.; Okada, M.; Tsunoda, K.; Aoi, K. A novel evaluation method for biodegradability of poly(butylene succinate-co-butylene adipate) by pyrolysis-gas chromatography. Polym. Degrad. Stab. 2001, 73, 327-334. [CrossRef]

24. Yang, H.-S.; Yoon, J.-S.; Kim, M.-N. Dependence of biodegradability of plastics in compost on the shape of specimens. Polym. Degrad. Stab. 2005, 87, 131-135. [CrossRef]

25. Wu, Y.; Wu, Y.; Xiong, W.; Zhou, H.; Li, H.; Xu, G.; Zhao, J. Biodegradation of poly (butylene succinate) film by compost microorganisms and water soluble product impact on mung beans germination. Polym. Degrad. Stab. 2016, 126, 22-30. [CrossRef]

26. Alshehrei, F. Biodegradation of Synthetic and Natural Plastic by Microorganisms. J. Appl. Environ. Microbiol. 2017, 5, 8-19.

27. Mohan, K. Microbial deterioration and degradation of Polymeric materials. J. Biochem. Technol. 2010, 2, 210-215.

28. Shah, A.A.; Hasan, F.; Hameed, A.; Ahmed, S. Biological degradation of plastics: A comprehensive review. Biotechnol. Adv. 2008, 26, 246-265. [CrossRef] [PubMed]

29. Butylina, S.; Martikka, O.; Kärki, T. Physical and Mechanical Properties of Wood-Polypropylene Composites Made with Virgin and/or Recycled Polypropylene. Polym. Plast. Technol. Eng. 2011, 50, 1040-1046. [CrossRef]

30. Shubhra, Q.T.H.; Alam, A.; Quaiyyum, M.A. Mechanical properties of polypropylene composites: A review. J. Thermoplast. Compos. Mater. 2011, 26, 362-391. [CrossRef]

31. Khoramnejadian, S.; Zavareh, J.J.; Khoramnejadian, S. Bio-based plastic a way for reduce municipal solid waste. Procedia Eng. 2011, 21, 489-495. [CrossRef]

32. Roy, S.B.; Shit, S.C.; Sengupta, R.A.; Shukla, P.R. Studies on biodegradabaility, morphology, physicomechanical and thermal properties of polyprylene/potato starch bio-composite. Int. J. Curr. Eng. Technol. 2015, 5, 1074-1084.

33. Dinh Vu, N.; Tran, H.T.; Nguyen, T.D. Characterization of polypropylene green composites reinforced by cellulose fibers extracted from rice straw. Int. J. Polym. Sci. 2018. [CrossRef]

34. Arkatkar, A.; Arutchelvi, J.; Bhaduri, S.; Uppara, P.V.; Doble, M. Degradation of unpretreated and thermally pretreated polypropylene by soil consortia. Int. Biodeterior. Biodegrad. 2009, 63, 106-111. [CrossRef]

35. Gu, J.D.; Lu, C.; Thorp, K.; Crasto, A.; Mitchell, R. Fiber-reinforced polymeric composites are susceptible to microbial degradation. J. Ind. Microbiol. Biotechnol. 1997, 18, 364-369. [CrossRef] [PubMed]

36. Shabani, F.; Kumar, L.; Esmaeili, A. A modelling implementation of climate change on biodegradation of Low-Density Polyethylene (LDPE) by Aspergillus niger in soil. Glob. Ecol. Conserv. 2015, 4, 388-398. [CrossRef]

37. Buzarovska, A.; Grozdanov, A.; Avella, M.; Gentile, G.; Errico, M. Poly (hydroxybutyrate-co-hydroxyvalerate) /titanium dioxide nanocomposites: A degradation study. J. Appl. Polym. Sci. 2009, 114, 3118-3124. [CrossRef]

38. Abderrahim, B.; Abderrahman, E.; Mohamed, A.; Fatima, T.; Abdesselam, T.; Krim, O. Kinetic thermal degradation of cellulose, polybutylene succinate and a green composite: comparative study. World J. Environ. Eng. 2015, 3, 95.

39. Jung, M.R.; Horgen, F.D.; Orski, S.V.; Rodriguez, V.; Beers, K.L.; Balazs, G.H.; Jones, T.T.; Work, T.M.; Brignac, K.C.; Royer, S.J.; et al. Validation of ATR FT-IR to identify polymers of plastic marine debris, including those ingested by marine organisms. Mar. Pollut. Bull. 2018, 127, 704-716. [CrossRef]

40. Liu, R.; Liu, M.; Cao, J.; Ma, E.; Huang, A. Fungi resistance of organo-montmorillonite modified lignocellulosic flour/polypropylene composites. Polym. Compos. 2018, 39, 3831-3840. [CrossRef]

41. Brzozowska-Stanuch, A.; Rabiej, S.; Fabia, J.; Nowak, J. Changes in thermal properties of isotactic polypropylene with different additives during aging process. Polymery 2014, 59, 302-307. [CrossRef] 
42. Al-Salem, S.M.; Sharma, B.K.; Khan, A.R.; Arnold, J.C.; Alston, S.M.; Chandrasekaran, S.R.; Al-Dhafeeri, A.T. Thermal degradation kinetics of virgin polypropylene (PP) and PP with starch blends exposed to natural weathering. Ind. Eng. Chem. Res. 2017, 56, 5210-5220. [CrossRef]

43. Mofokeng, J.; Luyt, A.S.; Tábi, T.; Kovács, J. Comparison of injection moulded, natural fibre reinforced composites with PP and PLA as matrices. J. Thermoplast. Compos. Mater. 2012, 25, 927-948. [CrossRef]

44. Reixach, R.; Puig, J.; Méndez, J.A.; Gironès, J.; Espinach, F.X.; Arbat, G.; Mutjé, P. Orange wood fiber reinforced polypropylene composites: Thermal properties. Available online: https://ojs.cnr.ncsu.edu/index.php/BioRes/article/viewFile/BioRes_10_2_2156_Reixach_Orange_W ood_Fiber_Polypropylene_Composites/3376 (accessed on 14 June 2019).

45. Salemane, M.G.; Luyt, A.S. Thermal and mechanical properties of polypropylene-wood powder composites. J. Appl. Polym. Sci. 2006, 100, 4173-4180. [CrossRef]

(C) 2019 by the authors. Licensee MDPI, Basel, Switzerland. This article is an open access article distributed under the terms and conditions of the Creative Commons Attribution (CC BY) license (http://creativecommons.org/licenses/by/4.0/). 